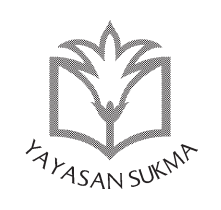

SUKMA: JURNAL PENDIDIKAN

ISSN: 2548-5105 (p), 2597-9590 (e)

Volume 3 Issue 2, Jul-Dec 2019, pp. 203-216

https://doi.org/10.32533/03204.2019

www.jurnalsukma.org

\title{
PENGGUNAAN KATA DAN ISTILAH BAHASA INGGRIS PADA PROMOSI PENJUALAN ONLINE DI INSTAGRAM
}

\author{
Nurul Fadzilatul Husna; Siva Nur Azizah; Mokh Yahya \\ Institut Agama Islam Negeri Surakarta, Indonesia \\ email: nurulpark1@gmail.com
}

\section{Abstract}

This study aims to find out diction errors in online sales promotions on Instagram. Twenty sentences have been taken from six accounts established in Solo, Central Java, as the samples. Analysis is focused on the inappropriate use of English words and terms. The results of this study are as follows. First, some forms of language errors found in Instagram accounts includes diction and terms errors. Second, the factors of language errors in sales promotions are (1) English is more popular, (2) English is more concise, (3) English looks more prestigious, and (4) English seems more persuasive. 
[Penelitian ini bertujuan untuk mengetahui kesalahan diksi dalam promosi penjualan online di instagram. Analisis data didasarkan pada dua puluh kalimat dari enam akun instagram di wilayah Solo Raya. Analisis difokuskan pada kesalahan diksi dan penyebabnya, yang dipilah menjadi dua bagian. Pertama adalah analisis penggunaan kata dan istilah bahasa Inggris dari segi makna dan gramatikal pada promosi penjualan di instagram. Kedua, faktor penyebab kesalahan berbahasa dalam penggunaan kata dan istilah bahasa Inggris yang disebabkan oleh (1) bahasa Inggris lebih populer, (2) bahasa Inggris lebih ringkas, (3) bahasa Inggris terlihat lebih bergengsi, dan (4) bahasa Inggris terlihat lebih santai dan persuasif.]

Keywords: language errors, English words and terms, instagram

\section{A. Pendahuluan}

Bahasa merupakan alat komunikasi manusia. Dengan bahasa manusia mampu berkomunikasi, bekerja sama, dan menyampaikan pendapat. Bahasa lisan merupakan bunyi yang dihasilkan oleh alat ucap manusia. Berbeda dengan bahasa lisan, bahasa tulis merupakan visualisasi bahasa lisan dalam bentuk huruf-huruf dan tanda baca. Dengan demikian, fungsi bahasa yang paling mendasar adalah sebagai sarana komunikasi. Selain itu, bahasa adalah alat pergaulan dan perbuhungan sesama manusia, sehingga terbentuk suatu sistem sosial masyarakat (Chaer 2006, 2). Komunikasi dalam masyarakat tentunya tidak hanya menggunakan satu bahasa saja melainkan dengan berbagai bahasa, salah satunya merupakan bahasa Inggis. Seperti yang diketahui diberbagai daerah dibanyak negara banyak sekali orang-orang yang mampu dan menguasai lebih dari satu bahasa. Sebagai contoh misalnya bahasa daerah dengan bahasa Indonesia atau bahasa asing dengan bahasa Indonesia. Apabila penutur menggunakan dua atau lebih bahasa yang digunakan, maka secara 
tidak langsung bahasa tersebut memiliki kontak atau saling keterkaitan.

Pada era sekarang penggunaan bahasa Indonesia dan bahasa asing seringkali digunakan oleh masyarakat secara bersamaan. Hal ini akan memungkinkan terjadinya kontak bahasa dan timbulnya pengaruh antara bahasa Indonesia dan bahasa asing tersebut. Hal ini terjadi karena penutur mampu menggunakan dua bahasa yang berbeda. Tingginya akses masyarakat terhadap aplikasi instagram serta perkembangannya yang semakin hari semakin populer yang didalamnya memuat berbagai informasi dari berbagai sumber yang berbeda dan beragam. Penggunaan bahasa asing ini banyak terdapat pada promosi yang dilakukan oleh pemilik akun penjualan online. Dengan ini disadari atau tidak konstruksi budaya yang dibangun media sosial tersebut memarginalkan bahasa Indonesia. Padahal seharusnya penggunaan media sosial memberikan contoh penguatan jati diri bangsa melalui penggunaan bahasa Indonesia yang tepat untuk menjaga kelestarian bahasa nasional, bahasa Indonesia.

Di lain sisi penggunaan media sosial yang dalam hal ini merupakan penggunaan aplikasi instagram digunakan oleh masyarakat dengan berbagai kebutuhan, baik itu memberikan argumentasi atau komentar terhadap suatu hal atau permasalahan, maupun mencari informasi mengenai hal-hal tertentu, serta sebagai hiburan dan lain lain. Hal yang menjadi persoalan dalam kajian ini adalah masih adanya kata dan istilah asing yang digunakan secara tidak tepat dalam promosi penjualan online oleh pemilik akun instagram. Penggunaan kata dan istilah bahasa Inggris pada promosi penjualan online di instagram banyak ditemukan. Walakin, tulisan dan caption pada instagram yang menggunakan istilah asing tersebut banyak menggunakan diksi yang tidak tepat.

Kesalahan penggunaan bahasa sering terjadi secara konsisten dan sistematis. Kesalahan bisa berlangsung lama apabila tidak diperbaiki. Kesalahan atau error mengacu pada setiap penyimpangan dari norma baku performasi bahasa tanpa 
mengindahkan atau memedulikan ciri-ciri atau penyebab penyimpangan tersebut (Tarigan 2011, 76). Dalam konteks penelitian ini, kesalahan berbahasa yang dimaksud adalah penggunaan bahasa secara lisan maupun tertulis yang menyimpang dari faktor-faktor penentu berkomunikasi atau menyimpang dari norma kemasyarakatan dan menyimpang dari kaidah tata bahasa.(Setyawati 2010, 13).

Analisis kesalahan berbahasa adalah suatu prosedur kerja, yang biasanya digunakan oleh peneliti dan guru bahasa, yang meliputi pengumpulan sampel, pengidentifikasian kesalahan yang terdapat dalam sampel, penjelasan kesalahan tersebut, pengklasifikasian kesalahan itu berdasarkan penyebabnya, serta pengevaluasian atau penilaian taraf keseriusannya (Setyawati 2010, 16). Dalam penggunaan bahasa Indonesia terdapat penggunaan diksi atau pilihan kata yang digunakan untuk membentuk suatu kalimat. Pilihan kata atau diksi pada dasarnya merupakan hasil dari upaya memilih kata tertentu untuk dipakai dalam membuat kalimat, alinea, atau wacana. Keraf juga menyatakan bahwa ada tiga hal utama mengenai diksi. Pertama, pengertian kata atau diksi mencakup kata-kata mana yang akan dipakai untuk menyampaikan suatu gagasan, bagaimana membentuk pengelompokan kata-kata yang tepat atau menggunakan ungkapan-ungkapan yang tepat dan gaya mana yang paling baik digunakan dalam situasi (Keraf 2007, 24). Kedua, pilihan kata atau diksi adalah kemampuan membedakan secara tepat nuansa-nuansa makna dari gagasan yang ingin disampaikan, dan kemampuan untuk menemukan bentuk yang sesuai (cocok) dengan situasi dan nilai rasa yang dimiliki kelompok masyarakat pendengar. Ketiga, pilihan kata yang tepat dan sesuai hanya dimungkinkan oleh penguasaan sejumlah besar kosakata atau perbendaharaan kata bahasa itu.

Sumber data dari penelitian ini adalah akun penjualan online di instagram area Solo Raya. Pemilihan ini dilatarbelakangi pemikiran bahwa instagram merupakan salah satu media sosial yang banyak di akses oleh masyarakat luas yang berkontribusi terhadap perkembangan bahasa Indonesia. Promosi dalam pen- 
Penggunaan Kata dan Istilah Bahasa Inggris pada Promosi Penjualan

jualan online di instagram ini dijadikan sebagai bahan penelitian dikarenakan dalam promosi penjualan online ini terdapat penggunaan kata dan istilah dalam bahasa Inggris. Data tersebut dikumpulkan menggunakan teknik dokumentasi dengan mendokumentasikan unggahan-unggahan yang berisi promosi online di instagram pada September s.d. Oktober 2019.

Penelitian serupa pernah dilakukan oleh Susetyo yang menyimpulkan bahwa penggunaan istilah asing mempengaruhi perkembangan bahasa Indonesia (Susetyo 2016). Sementara, Ayudia menganalisis kesalahan penggunaan bahasa di kalangan siswa SMP (Ayudia et. al. 2016). Kesalahan penggunaan diksi dalam bahasa Indonesia juga diteliti oleh Hidayatullah di Tangerang (Hidayatullah 2018) dan Yahya di Surakarta (Yahya et. al. 2018).

\section{B. Penggunaan Diksi Salah dalam Promosi di Instagram}

Bahasa Indonesia pada awal perkembangannya hingga saat ini telah mengalami banyak penyerapan unsur-unsur dari bahasa asing. Salah satunya merupakan bahasa Inggris yang memberi pengaruh kosa kata dalam bahasa Indonesia. Kata serapan dalam bahasa sejatinya merupakan hal yang wajar terjadi. Pada setiap kontak bahasa yang dilakukan oleh penutur pasti akan terjadi serap menyerap kata. Unsur-unsur asing inilah yang telah menambah sebagian besar kata kedalam bahasa Indonesia sehingga bahasa Indonesia mengalami perkembangan hingga sekarang sesuai tuntutan zaman (Susetyo 2016).

Dalam kajian ini ditemukan ketidaktepatan pemilihan kata yang terdapat pada akun instagram @caramel.purworejo berupa kesalahan penggunaan istilah asing. Kesalahan tersebut dapat dilihat pada frasa dan klausa: (1) new item dan (2) more info hubungi admin kami.

Diksi new item pada frasa (1) tidak tepat digunakan karena masih dalam bentuk bahasa asing. Dalam bahasa Indonesia diksi new item diterjemahkan menjadi produk baru. Pada klausa (2) terdapat bentuk bahasa asing berupa frasa more info. Dalam 
bahasa Indonesia diksi more info diterjemahkan menjadi info lebih lanjut. Agar klausa (2) menjadi lebih efektif, ditambah kata silakan.

Ketidaktepatan pemilihan kata yang kedua terdapat pada Akun instagram @nastarlaweyan yang berupa kesalahan pemilihan diksi yang tidak tepat, penggunaan istilah asing, dan penggunaan bahasa daerah. Kesalahan tersebut dapat dilihat pada kalimat: (3) Monggo ngicip Abon Gulung spesial dari @soloflossroll dan Nastar Balok kekinian by @nastarlaweyan; (4) (Disc. 15\% buat follower); (5) Wajib follow IG @soloflossroll dan @nastarlaweyan karna ada harga khusus bagi follower!!!

Kalimat (3) terdapat diksi by merupakan bahasa asing (bahasa Inggris). Dalam bahasa Indonesia diksi by diterjemahkan menjadi dari. Kalimat (4) terdapat diksi disc yang merupakan kependekan kata discount. Kata disc merupakan bahasa asing, bisa diganti dengan kata diskon. Kata buat juga kurang tepat digunakan dalam konteks kalimat. Agar kalimat menjadi efektif diksi buat bisa diganti dengan bagi. Diksi follower merupakan bahasa asing. Dalam bahasa Indonesia diksi follower diterjemahkan menjadi pengikut. Agar kalimat (5) lebih efektif, diksi wajib dan bagi follower sebaiknya dihilangkan. Terdapat juga diksi follow ig merupakan bahasa asing. Dalam bahasa Indonesia diksi follow ig diterjemahkan menjadi ikuti akun instagram. Agar kalimat menjadi efektif diksi karna ada sebaiknya diganti dengan dapatkan. Diksi khusus lebih baik diganti dengan spesial, karena lebih sesuai dengan konteks kalimat.

Perbaikan frasa dan klausa (3), (4), dan (5) sebagai berikut.

(3) Silakan mencicipi Abon Gulung spesial dari @soloflossroll dan Nastar Balok kekinian dari @nastarlaweyan.

(4) Diskon 15\% bagi pengikut.

(5) Ikuti akun instagram @soloflossroll dan @nastarlaweyan dapatkan harga harga spesial!

Ketidaktepatan pemilihan kata yang ketiga terdapat pada Akun instagram @solopluffy terdapat kesalahan pemilihan diksi 
Penggunaan Kata dan Istilah Bahasa Inggris pada Promosi Penjualan

yang tidak tepat, penggunaan istilah asing, dan penggunaan bahasa daerah. Kesalahan tersebut dapat dilihat pada kalimat berikut.

(6) Kalau Pluffia membeli 6 box akan mendapatkan tempat yang kece, keren, dan mudah untuk dibawa.

(7) Boleh dong share pendapat kalian di kolom comment, tentang bagaimana rasa varian Cheese cake dari Solo Pluffy ini.

(8) Jangan sampai weekend kalian tanpa Solo Pluffy yang nemenin ya.

(9) Waaaw so yummy, mana favorite mu?

Pada kalimat (6) terdapat kata kalau, kata tersebut kurang tepat karena kata kalau lebih tepat dalam konteks pembicaraan langsung (lisan). Agar kalimat menjadi efektif, kata kalau diganti dengan kata jika. Kalimat (6), (7), (8), dan (9) terdapat istilah bahasa inggris berupa box, share, comment, weekend, so yummy, dan favorite. Dalam bahasa Indonesia diksi tersebut diterjemahkan menjadi boks, bagi, komentar,akhir pecan, sangat lezat, dan favorit .

Perbaikan frasa dan klausa (6), (7), (8) dan (9) sebagai berikut.

(6) Jika Pluffia membeli 6 boks akan mendapatkan tempat yang kece, keren, dan mudah untuk dibawa.

(7) Boleh dong bagi pendapat kalian di kolom komentar, tentang bagaimana rasa varian Cheese cake dari Solo Pluffy ini.

(8) Jangan sampai akhir pekan kalian tanpa Solo Pluffy yang menemani ya.

(9) Waaaw sangat lezat, mana favoritmu?

Ketidaktepatan pemilihan kata yang keempat terdapat pada akun instagram@bigthings.hijab terdapat kesalahan pe- 
Nurul Fadzilatul Husna; Siva Nur Azizah; Mokh Yahya

milihan diksi dan penggunaan istilah asing. Kesalahan tersebut dapat dilihat pada kalimat berikut.

(10) READY STOCK

(11) START ORDER BESOK 2 OKTOBER 2019 JAM 10.00 WIB

(12) T-shirt Black

Pada frasa (10), (11), dan (12) terdapat diksi ready stock, T-shirt black, dan start order merupakan bahasa asing, Inggris. Dalam bahasa Indonesia diksi ready stock diterjemahkan menjadi tersedia,mulai pesan, dan kaus hitam.Agar kalimat menjadi efektif kata jam diganti menjadi pukul, karena menunjukkan waktu.

Perbaikan frasa dan klausa (10), (11), dan (12) sebagai berikut.

(10) Tersedia

(11) Mulai pesan BESOK 2 OKTOBER 2019 pukul 10.00 WIB

(12) Kaus hitam

Ketidaktepatan pemilihan kata yang kelima terdapat pada Akun instagram @soloprabu terdapat kesalahan pemilihan diksi yang tidak tepat dan penggunaan istilah asing. Kesalahan tersebut dapat dilihat pada kalimat berikut.

(13) Cuuss langsung sidakwae ning @soloprabu karena Soesayang reBrown mulai tersedia besok pagi!

(14) Outlet Solo Prabu Cake

(15) Open hours 08.00 - 21.00

(16) Pemesanan Online / Delivery

Pada kalimat (13) terdapat kata sidak, kata tersebut kurang tepat karena dalam KBBI kata tersebut memiliki makna inspeksi mendadak. Agar kalimat menjadi efektif, kata sidak diganti dengan kata menuju. Kata menuju memiliki makna mendatangi, pergi ke. Kalimat (13) masih menggunakan bahasa Jawa dalam 
Penggunaan Kata dan Istilah Bahasa Inggris pada Promosi Penjualan

mempromosikan produknya. Hal tersebut menjadi ciri khas akun @soloprabu dalam mempromosikan produknya.

Kalimat (14), (15), dan (16) terdapat istilah asing berupa Outlet, open hours, online, dan delivery. Dalam bahasa Indonesia diterjemahkan menjadi toko, buka pukul, daring, dan pengiriman. Pada kalimat (16) terdapat kata online, diganti dengan kata daring, yang memiliki makna dalam jaringan, terhubung melalui jejaring komputer, internet, dan sebagainya.

Perbaikan klausa dan kalimat (13), (14), (15), dan (16) sebagai berikut.

(13) Cuuss langsung menuju wae ning @soloprabu karena Soesayang reBrown mulai tersedia besok pagi!

(14) Toko Solo Prabu Cake

(15) Buka Pukul 08.00 - 21.00 WIB

(16) Pemesanan daring / pengiriman

Ketidaktepatan pemilihan kata yang kelima terdapat pada Akun instagram @rotibakarkukuspresiden terdapat kesalahan pemilihan diksi yang tidak tepat dan penggunaan istilah asing. Kesalahan tersebut dapat dilihat pada kalimat berikut.

(17) Roti bakar Greentea medium $14 k$

(18) Beli large atau large kombinasi free 2 slice roti kukus

(19) Yukkk ramaikan PROMO OPENING

(20) Cukup follow ig nya @rotibakarkukuspresiden dan tag temen2 kamu buat makan bareng2

Pada kalimat (17) terdapat kesalahan pemilihan diksi atau menggunakan istilah asing medium yang dalam bahasa Indonesia diterjemahkan menjadi sedang. Agar menjadi kalimat efektif kata medium diganti dengan kata sedang, yang mempunyai makna ukuran sedang. Pada kalimat (18) terdapat penggunaan bahasa asing large, free, dan slice jika diterjemahkan dalam bahasa Indonesia memiliki makna besar, gratis, dan mengiris. Agar menjadi 
kalimat efektif kata mengiris diganti menjadi potongan agar lebih tepat dengan kalimat setelahnya. Pada kalimat (19) dan (20) terdapat penggunaan bahasa asing opening, follow, dan tag. Dalam bahasa Indonesia memiliki makna pembukaan, mengikuti, dan menandai.

Perbaikan klausa dan kalimat (17), (18), (19), dan (20) sebagai berikut.

(17) Roti bakar Greentea ukuran sedang 14k

(18) Beli ukuran besar atau ukuran besar dengan kombinasi gratis 2 potong roti kukus

(19) Yukkk ramaikan PROMO PEMBUKAAN

(20) Cukup ikuti ig nya @rotibakarkukuspresiden dan tandai temen2 kamu buat makan bareng2

Dari berbagai pembahasan yang telah dijabarkan fenomena penyerapan bahasa Inggris dalam bahasa Indonesia hal tersebut ditunjukkan dengan berkembangnya bahasa Indonesia sesuai dengan perkembangan zaman.

\section{Faktor Penyebab Kesalahan}

Pada saat ini umumnya masyarakat lebih banyak menyukai kata-kata asing, terutama bahasa Inggris dalam berbahasanya daripada menggunakan bahasa Indonesia asli dengan baik dan benar. Anehnya mereka berpendapat bahwa penggunaan bahasa Inggris tersebut digunakan agar lebih mengena ke semua golongan masyarakat. Selain itu bahasa inggris juga dianggap lebih kreatif, efektif dan mudah pahami (Marsudi and Zahrok 2015, 101). Dengan adanya kontak bahasa, bahasa Indonesia sendiri telah mengalami perkembangan yang cukup besar. Misalnya pada kasta serapan yang merupakan kata dalam bahasa asing yang diserap ke dalam bahasa Indonesia. Sebagai contoh, kata serapan seperti standardization dalam bahasa Inggris diserap dalam bahasa Indonesia menjadi standarisasi, organization diserap menjadi organisasi, computer diserap menjadi 
Penggunaan Kata dan Istilah Bahasa Inggris pada Promosi Penjualan

komputer, dan sebagainya. Dengan dampak posistif ini maka bahasa Indonesia mampu berkembang sesuai dengan tuntuan zaman, mengikuti perkembangan dalam bidang politik, ekonomi, ilmu pengetahuan, dan teknologi.

Tetapi di lain sisi hal ini juga mempunyai pengaruh negatif yang tidak bisa diabaikan begitu saja. Pengaruh negatif yang dapat dilihat adalah mulai tergesernya bahasa Indonesia karena sebagain besar masyarakat Indonesia lebih mementingkan dan mempelajari bahasa Inggris yang dinilai lebih menjanjikan untuk kedudukan dan taraf ekonomi yang lebih baik. Akibatnya, bahasa Indonesia dapattergeser oleh bahasa Inggris (Marsudi and Zahrok 2015, 99). Dengan keberadaan bahasa Inggris sebagai bahasa internasional, pendidikan di Indonesia mulai dari tingkatan pendidikan dasar hingga pendidikan tinggi memilik kurikulum dan pelajaran bahasa Inggris. Hal ini dimaksudkan dengan tujuan sumber daya manusia mampu berperan aktif dalam era globalisasi. Hal ini merupakan sisi positif dari terjadinya kontak bahasa.

Namun hal lain yang tak kalah penting untuk diperhatikan adalah pengaruh bahasa Inggris terhadap bahasa Indonesia yang besar. Seringkali ditemukan fenomena pencampuran bahasa, penggunaan kata dan istilah asing yang digunakan secara bersamaan, berkombinasi dan campur aduk dengan bahasa asing dan lain sebagainya. Tentunya tidak butuh waktu lama bagi bahasa Inggris untuk menggeser eksistensi bahasa Indonesia itu sendiri. Perubahan bahasa Indonesia yang terjadi saat ini bukan hanya disebabkan karena perluasan tetapi juga berarti kemunduran yang selarah dengan apa yang terjadi di tengah masyarakat global. Dengan berbagai alasan yang melatarbelakanginya, seperti alasan ekonomi, sosial, dan politik. Masyarakat lebih merasa senang, terhormat dan merasa lebih intelek jika menggunakan bahasa Inggris. Kepopuleran bahasa Inggris inilah yang akan menggeser posisi bahasa Indonesia dalam pemakaiannya di masyarakat.

Di era yang sudah sangat maju ini masuknya pengaruh bahasa asing terhdap bahasa Indonesia tidak dapat dihindari 
lagi, khususnya bahasa Inggris yang kedudukannya lebih tinggi daripada bahasa Indonesia, selain itu bahasa Inggris juga merupakan bahasa international. Faktor-faktor penyebab terjadinya unsur-unsur bahasa Inggris yang masuk kedalam bahasa Indonesia yaitu: Pertama, bahasa Inggris lebih populer. Masyarakat lebih mengenal kata dan istilah dalam bahasa Inggris daripada bahasa Indonesia. Contoh, masyarakat lebih mengenal selfie daripada swafoto. Hal ini menunjukkan bahwa ketertarikan masyarakat dalam mencari padanan kata yang baku dalam bahasa Indonesia masih sangat rendah. Kedua, bahasa Inggris lebih ringkas. Umumnya hal ini gunakan dalam bahasa lisan maupun tulisan. Contoh, masyarakat terutama dari kalangan remaja seringkali menggunakan kata dan istilah bahasa Inggris seperti fyi yang merupakan kependekan dari for your information jika diterjemahkan dalam bahasa Indonesia menjadi informasi untukmu, selain itu pada promosi penjualan online di instagram seringkali menggunakan kata dan istilah bahasa Inggris $c p$ yang merupakan contact person dalam bahasa Indonesia berarti orang yang bisa dihubungi atau narahubung.

Ketiga, bahasa Inggris terlihat lebih bergengsi. Hal ini disebabkan karena bahasa Inggris merupakan bahasa International, masyarakat merasa lebih disegani atau dianggap lebih intelek dan terhormat jika menggunakan kata dan istilah dalam bahasa Inggris. Keempat, bahasa Inggris terlihat lebih santai dan lebih menimbulkan keakraban. Dalam hal ini penjual online penggunakannya untuk menarik minat pembeli. Karena, bahasa Inggris memberikan kesan santai. Berbeda jika menggunakan bahasa Indonesia yang meberikan kesan kaku dan formal dalam interaksi jual beli. Kelima, menggunakan bahasa Inggris terlihat lebih profesional. Banyak penjual online di instagram maupun dalam dunia nyata menggunakan ini untuk memberikan label pada merek yang dijualnya dengan tujuan untuk membangun dan membesarkan sebuah produk. Dengan menggunakan bahasa Inggris, suatu produk yang dijual terkesan mempunyai merek yang tinggi. Penjualnya menggunakan bahasa Inggris ini disesuaikan dengan siapa saja atau dari kalangan apa konsumen tersebut. 


\section{Penutup}

Pada analisis yang telah dijabarkan pada pembahasan di atas telah ditemukan kesalahan pemilihan diksi dan penggunaan kata dan istilah bahasa Inggris pada promosi penjualan online di instagram. Kesalahan tersebut meliputi (1) penyerapan, (2) penggunaan, dan (3) penulisan kata dan istilah bahasa Inggris pada promosi penjualan online. Fenomena ini menunjukkan terjadinya kontak bahasa serta masuknya unsur-unsur bahasa asing kedalam bahasa Indonesia, terutama bahasa Inggris.

Tentu ada penyebab terjadinya fenomena tersebut, diantaranya karena bahasa Inggris merupakan bahasa internasional yang mempunyai kedudukan lebih tinggi dan lebih popular dibanding bahasa Indonesia. Sehingga penjual online di instagram lebih sering menggunakan istilah dan kata bahasa inggris pada promosi penjualannya, karena bahasa Inggris dianggap mempunyai nilai jual yang lebih tinggi. Selain itu penjual juga lebih akrab dengan kata dan istilah bahasa Inggris. Dan masyarakat lebih senang menggunakan bahasa Inggris karena dianggap terlihat lebih intelek dan terhormat serta mempunyai gengsi yang lebih tinggi. Hal ini merupakan salah satu sisi positif dari terjadinya kontak bahasa. Bahasa Indonesia berkembang dan mampu menyelaraskan dengan berbagai tuntutan perkembangan zaman, baik dari segi politik, sosial, ilmu pengetahuan maupun teknologi. Disisi lain hal yang mengkhawatirkan juga terjadi, yaitu tergesernya eksistensi bahasa Indonesia oleh bahasa asing. Maka dari itu sebagai pengguna bahasa Indonesia sudah seharusnya terus mengembangkan bahasa Indonesia untuk kepentingan di masa depan agar posisi bahasa Indonesia tidak tergeser dengan eksistensi bahasa asing di era globalisasi.

\section{BIBLIOGRAPHY}

Ayudia et. al. 2016. "Analisis Kesalahan Penggunaan Bahasa Indonesia." Jurnal Basastra 4 (1).

Chaer, Abdul. 2006. Tata Bahasa Praktis. Jakarta: PT Rineka Cipta. Hidayatullah, Ahmad. 2018. "Analisis Kesalahan Diksi Pada 
Nurul Fadzilatul Husna; Siva Nur Azizah; Mokh Yahya

Karangan Siswa Kelas IX SMP Islam Daar El-Arqam Tangerang." Jurnal El-Banar 1 (1).

Keraf, Gorys. 2007. Diksi Dan Gaya Bahasa. Jakarta: PT Gramedia Pustaka Utama.

Marsudi, and Siti Zahrok. 2015. "Kesetiaan Berbahasa Indonesia Dipertanyakan Di Era Globalisasi." Jurnal Sosial Humaniora 8 (1).

Setyawati, Nanik. 2010. Analisis Kesalahan Bahasa Indonesia. Surakarta: Yuma Pustka.

Susetyo, Agus Milu. 2016. "Penggunaan Kata Dan Istilah Bahasa Inggris Pada Rubrik Opini Dalam Surat Kabar Kompas." Jurnal Belajar Bahasa 1 (1).

Tarigan, Henry Guntur. 2011. Pengajaran Analisis Kesalahan Berbahasa. Bandung: Percetakan Offset Angkasa.

Yahya, Mokh et. al. 2018. "Studi Kesalahan Kalimat Dalam Karangan Pelajar Bahasa Indonesia Bagi Penitur Asing (BIPA)." Jurnal Dialektika 5 (1). 